\title{
Artaud-Immunity: Derrida and the Mômo
}

More than the working through of a fascinated ambivalence, Derrida's returns to Artaud chronicle a sustained and determined campaign of immune defence. Yet what sets his 'little pieces on Artaud' apart from the dominant strategy of Artaud-immunisation inaugurated by the Correspondance avec Jacques Rivière (1924) is their refusal of the distinction between the 'clinical' and the 'critical'. His essays of the 1960s 'La parole Soufflée' and 'The Theatre of Cruelty and the Closure of Representation' began the search for new ways to secure Artaud-immunity continued in forcener le subjectile (1986) and Artaud le Moma (2002). He understood that Artaud not only evaded Rivière's defence of literature against his madness but also pre-empted all future attempts to mobilise the 'clinical/critical' distinction against them. This awareness gives Derrida's readings of his 'privileged enemy' over their thirty years war (Derrida 2002, 19) a singular power and urgency among the philosophical readings of Artaud, but one whose strategic compromises and evasions bore consequences that extended beyond the immediate aim of securing Artaud-immunity.

For Derrida, Artaud posed the problem of how to read an oeuvre whose defences had been preemptively disabled in an auto-immune reaction to anticipated rejection that seemed to verge on the suicidal. His readings of Artaud's highly immunised texts and drawings were precursors of the formal inquiry into auto-immunity initiated in Faith and Knowledge (1998) and pursued up to Rogues: Two Essays on Reason (2005) and prepared for their understanding of auto-immunity as suicidal. The limits of Derrida's understanding of auto-immunity are set by his Artaud-immunity that underestimated Artaud's counter-resistance as a chaotic Platonism in which the lowering of defences was anything but suicidal.

\section{Resistance and Counter-Resistance or the Return of the Celestial Poet}

Artaud's first steps towards immunising his work against clinical and critical resistance were taken in his correspondence with Jacques Rivière, an editor with La Nouvelle Revue Francaise. It was the publication of this epistolary testament to rejection that brought Artaud's work to the attention of a wider public including the adolescent Derrida. The correspondence of poet and critic begins inauspiciously with a rejection letter dated May 1, 1923 in which Artaud learns that Rivière is regretfully 'unable to publish your poems in La Nouvelle Revue Francaise' (Artaud 1976, 31). The 
critic adds, though, that the unacceptable poems aroused his interest sufficiently to want to meet their author. In the letter following this meeting dated June 5 1923, Artaud responds to Rivière's refusal to admit the poems into the realm of French literature as policed by the $N R F$ by referring to the 'the acceptability of these poems' and the problem of their survival or 'literary existence' following rejection. He immediately cites the 'horrible sickness of the mind' that afflicts his thought and expression, pre-empting Rivière's view that while his poems fail as literature they succeed as clinical symptoms. In the face of such rejection - the resistance of a reasoned literature to his mad poems - Artaud invokes another literature where 'the right to speak' is justified by suffering. It is not that he wants his poems to be recognised as literature; he wants them to threaten the very institution of literature. Artaud and Rivière commence a war of resistance and counter-resistance with each responding to the other with prudence and suspicion. Rivière replies on March $25^{\text {th }} 1924$, defending his rejection of the poems against the sufferer's claimed 'right to speak' and deporting them to the clinic, converting their challenge to literature into symptoms of Artaud's psychopathology.

With this gesture Rivière opened a season of Artaud critique (or rather diagnosis) that has still to run its course, but whose success as an immune strategy was unwittingly compromised at ithe outset. For Rivière felt impelled to publish the correspondence in place of the unpublishable poems. For if literature cannot tolerate the poems, it can, perhaps must, display its successful immune defence as an exemplary neutralisation of a potential threat. Artaud agrees to this proposition and the letters were published with, secreted in a postscript, one of the 'unpublishable' poems 'Cry' (Artaud 1976, 37-8). This poem became emblematic of Artaud's work, entering literature disguised as a clinical expression that in 8 stanzas and an envoi thematises immunity and the evasion of its defences. It begins with the 'little celestial poet' opening 'the shutters of his heart' and letting the cosmic catastrophe flood in to undo his harmonies or 'symphony'. Following this catastrophic infection the second stanza introduces the antagonist - the stableboy of the crazy house who remains unaware that the fury of the heavens has been unleashed on him. The third stanza explains the stable-boy's task of guarding the house by silencing impurity, an open reference to the NRF's commitment to purity of expression evoked by Rivière in the correspondence. Against this the poet poses the question: if the world is full of impurity, what is left when it is 'muzzled' if not just silence and the night. The stable boy's purity and perfection are words for death, themselves 
more mad than the celestial poet's opening his heart and lowering his defences against impurity and catastrophe.

The poem then introduces a cosmo-phagic star (ally of the celestial poet) that eats the heavens and then itself, leaving only night. But this is not the night of morbid purity since its darkness differs radically from that of the stableboy. The star consuming itself can be reborn, while in the silence and the night of the stableboy's confined perfection there remains only a slug - the institution of literature - whose transit, saluted by ten thousand white hands shuffling its pages, makes its way across an obliterated earth. In the sixth stanza, the poem leaves the slug making its acclaimed trail across nothingness to return to the celestial poet. The peaceful retreat of the angels from a vacated cosmos is interrupted by the call of the 'real voice of the Spirit' and thus - inverting the Gospel of John for here at the end is the word - everything begins again in a delirious repetition of creation that in the eighth stanza culminates in the underground sun vapourising the sea after which 'A dream strange but clear/was born on the earth gone mad'. (Artaud 1976, 37) Apostle John's word made flesh that opened the history of spirit is rewritten as the eschatological word made vapour of an impossible re-creation. The eighth and final stanza of the poem's main sequence returns edgily to its catastrophic opening, except that now the 'celestial' has become the 'lost poet' or philosopher who leaves the heavens, perhaps for the mad earth, perhaps for nowhere, carrying 'an idea from beyond the earth' but with the shutters of his heart overgrown with luxuriant, protective hair... In the envoi Artaud presents more formally the encounter of the poet and the guardian of literature, reflecting on what happened in the correspondence - 'two traditions met,/ but our padlocked thoughts did not have sufficient room' - but ending the poem with the optimistic instruction 'Experiment to be repeated' (Artaud 1976; 37-38).

Beyond performing the failure of the correspondence, 'Cry' is remarkable for evading the defences of the stable-boy and entering literature encrypted as a symptom. 'Experiment to be repeated' indeed, and often, for even if the two padlocked thoughts - those of the mad poet and the vigilant stable-boy - did not have room to open to each other, and even if this contraband poem was only allowed to exist under the mask of delirium, there nevertheless remained sufficient space to at least imagine a future for the experiment. Artaud unpicked the critical padlock with this poem, and then infiltrated it into the stable of literature. His subsequent works apply this lesson in evading immune defences by pre-empting the strictures of clinic and critique. The critical and clinical strategy of containing the poems and so immunising literature from madness would prove a patent failure. 
Artaud's preferred strategy remained the one declared by the celestial poet, opening the shutters to madness. After all, it makes no sense to charge the man who steps before the public as the Mômo with being mad: claiming the right to speech in the name of madness pre-empts any appeal to clinical suppression. In the Correspondence avec Jacques Rivière Artaud claims both madness disabling the defences of reason - and the right to speak; he cannot be silenced by the accusation of madness since he claims to speak in the name of its suffering. The resistance is countered in advance and the struggle for the word moved to a different level.

\section{Defencelessness or to be done with naiveté}

Derrida's first skirmish in his thirty years war with the celestial poet - 'La parole soufflée' published in Tel Quel in 1965 and then in Writing and Difference (1967) - reviews Rivière's clinical/critical resistance to Artaud (re-mobilised in the early 1950s by Blanchot) and sets out in search of more subtle and effective Artaud-immunising strategies. The opening sentence of 'La parole souflée' evokes 'naiveté' or defencelessness when attempting to speak to and of Artaud. Presciently Derrida suspects that 'it would take a long time' to diminish this defencelessness or to build up Artaud-immunity, but begins by reworking Blanchot, Foucault and Laplanche's fidelity to Rivière's strategy. His reworking does not repeat Rivière's defence of 'critical' by resort to 'clinical' discourse but sets both in a dialogue 'borne upon that which is beyond their two trajectories, pointing toward the common elements of their origin and their horizon' (Derrida 1967, 212). With Foucault's stricture at the end of The History of Madness firmly in mind, this strategy appeals to the enigmatic conjuncture of 'madness and the work'. Literature cannot be defended by relegating Artaud's work to the realm of clinical symptom, but must rethink the conjunction of madness and work that it achieves. Attentive to Artaud's call in the Correspondence avec Jacques Rivière that literature must change in order to receive his work, Derrida avoids speaking of a clinical and critical relation out of vigilance for the singular threat posed by the conjuncture of work and madness that is Artaud. To describe this in terms of a modal relation reduces Artaud to an example of a larger operation - the history of literature expanding before the challenges to its limits - and mobilises a repertoire of strategic gestures no longer effective before the pre-immunised and thus singular threat of the Mômo.

Blanchot, Laplanche and Foucault's subtle adjustments to the critical/clinical strategy met a difficulty Derrida recognised as common to all pharmacological resistances; they expose through 
their very effort to protect: 'At the moment when criticism (be it aesthetic, literary, philosophical, etc.) allegedly protects the meaning of a thought or the value of a work against psycho-medical reductions, it comes to the same result through the opposite path: it creates an example. That is to say, a case.' (Derrida 1967, 214) Blanchot's reading of Artaud in The Book to Come is reproached for effecting this reduction; it immunises the work from the madness of Artaud by making his 'entire adventure' 'only the index of a transcendental structure' (Derrida 1967, 213), albeit a mad one. Derrida recognises this as a replay of Rivière's strategy, sugared with negative-dialectical ornamentation but fundamentally vulnerable to Artaud pre-emptive strategy. The same holds for Laplanche who, while critical of Blanchot, ends by regarding the work (of Hölderlin) as a privileged example of madness that offers symptomatic access to the experience and understanding of schizophrenia. Derrida is wary of protecting this exemplary madness, even more of defending a violated singularity from critical violence: 'it is not because we think, and this credit will have to be granted us, that subjective existence, the originality of the work or the singularity of the beautiful, must be protected against the violence of the concept by means of moral and aesthetic precautions.' (Derrida 1967, 218) He is careful not to invest in the sentimental scenario of immunising a victim against the violence of the critical or clinical concept about to be applied to them, since this fatally underestimates the threat posed by Artaud. Artaud showed himself tactically aware in the Correspondence avec Jacques Rivière of how to disarm by exploiting the 'moral and aesthetic' scruples of the 'stableboy' before the mad poet. Derrida at this point attempts to invent a new strategic portfolio tailored to the singular 'encounter' in his 'war' - with Artaud. He reasons the need to intensify this violence, to respect his enemy and to learn from the 'defeats' of his sentimental predecessors whose appeal to critical and clinical authority disabled their defences and prevented them from building up sufficient Artaud-immunity.

And so the essay begins again, returning to naiveté which, in case we had not realised it, 'was not a stipulation of style' (Derrida 1967, 219) but always that defensive strategy of the calculated lowering of defences. Throwing away the defence doctrine of Rivière and the Neo-Rivièrians provoked one of the first intense bursts of strategic reflection to emerge from Derrida's Artaud wars. It is vital never to underestimate the Mômo, for he is engaged in a war of absolute resistance: 'If Artaud absolutely resists - and, we believe, as was never done before - clinical or critical exegeses, he does so by virtue of that part of his adventure (and with this word we are designating a totality anterior to the separation of the life and the work) which is the very protest itself against exemplification itself. The critic and doctor are without resource when confronted by an existence 
that refuses to signify, or by an art without works, a language without a trace.' (Derrida 1967, 219) This is a war of resistance that pre-emptively addressed 'the history of dualist metaphysics which more or less subterraneously inspired the essays invoked above [by Blanchot, Foucault and Laplanche]' (Derrida 1967, 219) as well as the structure of theft by an invisible souffleur or prompter in the theatre who ensures the actor's fidelity to the text being played.

Derrida describes the function of the invisible prompter with a signature neologism: 'it ensures the indispensable différance and intermittence between a text already written by another hand and an interpreter already dispossessed of that which he receives.' (Derrida 1967, 221) Ensuring the respect of différance is the strategy pursued by Artaud's enemy; but had not Artaud already pre-empted the protection offered by différance and the souffleur by implicating them in the metaphysical scene? In defending différance against Artaud, the souffleur cannot simply repeat the metaphysical text since this is already compromised, but if he does not, then he is no longer a souffleur no longer an invisible guardian of the text but a conscript for the theatre of cruelty. How then can the souffleur ensure respect of différance without cruelty? He must begin by recognising the level of threat posed by his adversary: 'Artaud desired the conflagration of the stage upon which the prompter [souffleur] was possible and where the body was under the rule of a foreign text. Artaud wanted the machinery of the prompter [souffleur] spirited away [soufflé], wanted to plunder the structure of theft. To do so, he had to destroy, with one and the same blow, both poetic inspiration and the economy of classical art, singularly the economy of the theatre. And through the same blow he had to destroy the metaphysics, religion, aesthetics etc., that supported them.'(Derrida 1967, 221) Derrida will return Artaud's blows thirty years later, when he will be just as clear that these blows were directed at him and that he always knew how to parry them.

What does Artaud put in the place of the security and protection offered by the souffleur - the invisible guarantor of the text and protector of the actor against the lapse of memory? Derrida, looking out from the little booth at the front of the classical stage of metaphysics, appreciates the gravity of the threat: 'He would thus open up to Danger a world no longer sheltered by the structure of theft. To restore Danger by reawakening the stage of cruelty - this was Antonin Artaud's stated intention at the very least.' (Derrida 1967, 221) And it is here that Derrida perceives a weak point in Artaud's metaphysical immunity; a self-disabling of his own lines of defence in the name of exposure to Danger. Derrida detects a 'calculated slip' in this opening to Danger, but is sure enough of his enemy to be unsure whether the 'flaw' is not a trap. Artaud evades the fixed defences of 
metaphysics manned by Rivière and his proteges by lowering his defences and abandoning the protection they seem to offer. The calculated lowering of the defences of reason permits Derrida to prompt Artaud: 'Loss, precisely, is the metaphysical determination into which I will have to slip my works if they are to be understood within a world and a literature unwittingly governed by the metaphysics for which Jacques Rivière served as a delegate' (Derrida 1967, 222) Having to lower defences, to claim silence and irresponsibility prior to affirming Danger seems to open a chink for souffleur to enter and steal Artaud's words. And Derrida does so - for who else is the 'I' slipped into this passage ('I will have to slip...') who would evade the metaphysics of Rivière than the souffleur speaking for Artaud, prompting Artaud. The lowering of defences (auto-immune cruelty) and the opening to Danger permits the return of the prompter, who ensures that Artaud properly performs Artaud, that is to say, cruelly betrays himself.

Derrida's is not a critical or clinical assessment of Artaud, but an infiltration, a viral overriding of Artaud-immunity that protects it while prompting its exposure to danger. Artaud's cruelty is faithfully performed on the proscenium stage of metaphysics guarded over by the invisible souffleur. But perhaps Artaud's vulnerability at the moment of lowering defences is feigned, a decoy in the spirit of Sun Tzu that makes a noise in the east before attacking from the west? Derrida gives the possibility a full airing but only to expose the strategic weaknesses of the souffleur. Speaking as ever for Artaud, prompting him here in the name of his true desire, Derrida mimes his opposition to the scenario of loss imposed by having to disable his metaphysical defences. He (the souffleur is giving him the words) $h e$ 'wants to explode it. He opposes to this inspiration of loss and dispossession a good inspiration, the very inspiration that is missing from inspiration as loss' (Derrida 1967, 224-5) And yet 'he' by saying so, is recaptured by the metaphysical opposition between good and bad inspiration. Making Artaud speak in this way underestimates the poet's capacity to resist, his own Artaud-immunity. For Derrida can only imagine such self-disabling of defences as suicide followed by rebirth: 'This is why - such is the concept of true suicide according to Artaud - I must die away from my death in order to be reborn "immortal" at the eve of my birth' (Derrida 1967, 228). Yet, ever the souffleur, the prompts by which Derrida leads Artaud to this onto-theological terminus are not entirely apt, and forget Artaud's direct and sustained attacks on the gesture of suicide: the celestial poet was not suicided by the cosmos. His objections - to take his voice against Derrida's taking his voice - maintain that embracing danger by suspending defences only appears suicidal from the secured standpoint of metaphysics. Indeed, Derrida's 
consistent alignment of auto-immunity with suicide - the self robbing itself of its own life originates in this moment of translating Artaud-immunity into the Latin sui-cide.

Derrida ends by revealing his strategy and the line of fortification he has erected against Artaud. It comprises a cruel manoeuvre in which the erstwhile prompter metamorphoses into a choreographer, producing the spectacle of Artaud walking the line between murder and resurrection: 'One entire side of his discourse destroys a tradition which lives within difference, alienation, and negativity without seeing their origin and necessity. To reawaken this tradition, Artaud in sum, recalls it to its own motifs: self-presence, unity, self-identity, the proper etc. '(Derrida 1967, 244) . After de/ prescribing these actions Derrida lends them metaphysical character: 'Artaud's "metaphysics," at its most critical moments, fulfils the most profound and permanent ambition of Western metaphysics.' (Derrida 1967, 244) But in a final twist, Derrida detects in this a cruel 'law of difference' a fixed line of defence where Artaud abandons 'metaphysical naiveté'. The restoration of defences, the abandoning of the defenceless posture that Derrida feigned at the outset of his essay, thus renders Artaud's defensive and offensive strategy transparent to his enemies.

Derrida explicitly identifies these movements as part of a devastating stratagem on Artaud's part, all the deadlier for never being explicitly disclosed: 'The duplicity of Artaud's text, simultaneously more and less than a stratagem' (Derrida 1967, 244) has 'unceasingly obliged us to pass over to the other side of the limit' (Derrida 1967, 244). Yet this disarming avowal is not all it would seem, since Derrida is not just maintaing a bi-polar offensive posture with respect to Artaud as recommended by the Maoist doctrine close to the editors and readers of Tel Quel - when Artaud destroys Derrida preserves, when Artaud preserves, Derrida destroys - but is setting himself to reveal naiveté as a tactic. By exposing Artaud's denunciation of the 'naïve implications of difference' from a position that feigns 'the closure of presence' he will claim that this exposure compromises Artaud's immune strategy. So while admitting that he might seem to be 'criticising Artaud's metaphysics from the standpoint of metaphysics itself,' this is but a feint since his real strategy consists in 'delineating a fatal complicity' in Artaud. The complicity is 'fatal' for prompting a hiatus between lowering defences and affirming danger that is the vulnerable point of Artaudimmunity, namely that 'necessary dependency of all destructive discourses: they must inhabit the structures they demolish, and within them they must shelter an indestructible desire for full presence, for nondifference: simultaneously life and death'.(Derrida 1967, 244-5) But we already saw that understanding this life/death as a suicidal gesture underestimated Artaud's defences, since 
for him immunity is not suicidal but, we shall see, chaotic. The essay ends with a tactical retreat as Derrida appreciates that his strategy of revealing the tactical deployment of complicity while much more supple and apparently effective than the clinical/critical distinction of Rivière et.al., had already been anticipated by Artaud. The souffleur does not really believe that performance of Artaud just concluded ends in the life that chooses death or suicide.

\section{Avoiding Chaos or the Perversion of Metaphysics}

Derrida was aware that Artaud's madness was part of his studied, even scholastic perversion of Platonism. His suspicion that Artaud's 'metaphysical rage for re-appropriation' (Derrida 2002, 20) was complicit with metaphysics and available for deconstruction was persistent and well-founded. Yet he also knew that his prompt of Artaud's suicidal demolition of metaphysics barely approximated the precision and power of Artaud's anti-metaphysical rage and its proximity to the theatre of cruelty. This is clear from Artaud's remarkable 'Mis-en-scène and Metaphysics' - a key essay in the collection The Theatre and its Double published by Gallimard on the eve of Artaud's incarceration in 1938. This essay shows an Artaud not so much complicit with Platonism than actively and cruelly perverting it. From the initial step of replacing the idea of reason or nous with madness in the response to Rivière, Artaud moves in this essay towards an internally articulated, chaotic platonism.

Artaud sees Lucas van den Leyden's Lot and his Daughters in the Louvre as an scene from the end of the world choreographed as a procession of perverted Platonic ideas. The procession first appears as a detail in the painting - a 'bridge, high as an eight story house, rising over the sea, and across which figures are parading single file like the ideas in Plato's cave' (Artaud 1938, 230; 522) and then extends across the entire painting. But these are not the canonical ideas of Being, the One, the Good, the True and the Beautiful that populate the Platonic and neo-Platonic firmament but their cruel perversions. Projected on the walls of Artaud's cave are the shadows of the ideas of sexuality and reproduction, 'with Lot seemingly placed there to live off his daughters like a pimp' (Artaud $1938,230 ; 524)$ that undo the Platonic family romance that would so fascinate Derrida in 'Plato's Pharmacy,' followed by a procession of perverted substitutes. In Artaud's procession the idea of Becoming takes the place of Being, followed by the idea of fatality that brings both organisation and disorganisation to the subordinate ideas that succeed it. The place of the One is assumed by the idea of Chaos followed by the ideas of the miraculous, of equilibrium and finally the idea of aphasia 
or 'impotences of speech' that replaces the logos of truth. In this procession the cardinal ideas of Being, the One, and the Logos are twisted into Becoming, Chaos, and Aphasia. The world is still governed by a procession of ideas - is still metaphysical - but the ideas themselves have undergone a cruel sea-change in Artaud's hands .

Artaud strategically affirms the ideas and his concession that he is 'reluctant to use that word' metaphysics (Artaud 1976, 230) is a disarming diversion. His Platonic mis-en-scene has already second-guessed the deconstructive gesture to come, and moreover flaunts its immunity by describing that mis-en-scene as the theatre of cruelty. For after deciphering the procession of perverted ideas in Lot and his Daughters Artaud moves immediately to his attack on Western Theatre. In the foreground is the Platonic cave and its status as the mis-en-scene of both tragedy and its philosophical critique. The perverted Platonism evoked by Artaud requires not only a new cave but also the rejection of the inaugural Greek liaison between philosophy and tragic drama located in the Platonic dialogue. As Nietzsche showed in the Birth of Tragedy, Euripidean theatre's commitment to dialogue was part of its debt to philosophy, a debt renounced in Artaud's theatre of cruelty. Not only theatre, but philosophy must be freed from its confinement to dialogue and the logos. The new mis-en-scene will not be the mural screen of Plato's cave but ' a physical and concrete place' where a 'concrete' aphasic language 'independent of speech' is uttered in a way that addresses all the senses. The poetry of language - bound up in the relation of the Logos of Truth with the ideas of Reason, Being, the One the Good and the True - recedes before the 'poetry of space' made up of 'physical images' governed by the idea of chaos. These images inhabit a Platonic mis-en-scene: Becoming, Madness and Chaos are not expressed through the logos, but through the governing idea of aphasia.

The theatre of cruelty that renounces Western and Latin theatre of written text, language and dialogue seems to pose a difficult case for deconstruction. It has pre-emptively declared itself metaphysical while remaining inimical to the Latin investment in the idea as written text and to speech and the logos. Artaud discards the Latin/Western strategy of securing the audience's conviction through reasoned, dramatic, dialogical speech in the philosophical drama; his audience is exposed less to conviction than to contagion. The first essay of The Theatre and its Double equates the theatre with plague, an equation described in terms of the darkening of Platonic eros by the Latin/Western libido that for Artaud sickened life. He dreamt of supplanting the theatre of speech, dialogue and light with another, openly cruel and professedly epidemic, which 'Invites 
spirit to a delirium that enhances its energies.' (Artaud 2004, 520) While there can be no return to Platonic eros as the liaison between the world and ideas, Artaud sees in the madness and enhanced energy of the theatre of cruelty an antidote to the poisons of reason and libido.

The theatre of cruelty is professedly anarchic, but anarchic by Platonic principle; it is an anarchy governed, paradoxically, by the energetic law that participates the ideas of Chaos, Becoming and Speechlessness - 'crowned anarchy' in the formula of Artaud's manifesto for a perverted Platonism Héliogabale ou l'anarchiste couronné (1934). This might appear as much a cruel and prescient undoing of logocentrism as an unrepentant metaphysical affirmation of presence; but it is neither, or rather it is the strategic perversion of both. Artaud's writings are in both cases immunised against any hasty critique or deconstruction; hence the extreme care with which Derrida handles them, deploying a level of precaution against contagion unique to his work. For Artaud is a singular enemy whose power of contagious madness has to be approached with care. Derrida's war consists in resisting contagion from a highly immunised pathogen that presents itself as totally exposed. The philosopher must enter the cave prepared, but in the case of the theatre of cruelty they must be immunised against the contagion of the ideas of chaos, becoming and a language that is not logos but 'anarchic insofar as its appearance is the consequence of a disorder that brings us closer to chaos' (Artaud 1976, 236).

Derrida's second confrontation with Artaud in Writing and Difference - The Theatre of Cruelty and the Closure of Representation' 'delivered at the Artaud colloquium' in April 1966 and published in Bataille's Critique in the same year - professes to engage directly with 'all the texts' of The Theatre and its Double, regarding them as 'more solicitations than a sum of precepts, more a system of critiques shaking the entirety of Occidental history than a treatise on theatrical practice.' (Derrida 1967, 296). And yet it remains reticent about the strategic perversion of Platonism Artaud ventured in Mis-en-scène and Metaphysics' and limits itself to addressing only one aspect of it. Artaud's perversion of Platonism's cardinal ideas follow each other in a choreographed procession but Derrida approaches them selectively: he focuses on Logos, and to a lesser extent Being but does not engage chaos. The selective reception of Artaud's perversely systematic procession is essential to Derrida's 'complicity with metaphysics' deconstructive strategy, but operates on too narrow a front to provide effective protection. Leaving unanalysed the idea of chaos articulated in 'Mis en scène and Metaphysics' and largely shunning this essay - Artaud's most extended and considered 
reckoning with metaphysics - allows this idea to wreak its effects on Derrida's exposed and vulnerable texts.

Derrida dissembles a distance from the 'complicity with metaphysics' strategy pursued in the parole soufflée by emphasising the affirmative character of the theatre of cruelty: 'It affirms, it produces affirmation itself in its full and necessary rigour' (Derrida 1967, 293). Here Derrida uncouples affirmation and negation, abandoning the defensive posture of the previous essay that required their complicity. The affirmation of the theatre of cruelty does not require any dialectical negation of past theatres but opens of its own necessity. The void it would fill has not been hollowed out within conventional theatre, but is affirmed as 'the space of this unique opening of this distance' (Derrida 1967, 294). Yet the character and extent of this affirmative opening is very quickly limited, first by regarding this affirmation - 'the theatrical practice of cruelty' - as the expulsion of God from the stage, which is to say, in spite of all the earlier precautions, an act still scarred by dialectical negation. And after demolishing the stage of onto-theology all that is left for this affirmation to do, for Derrida, is live with the legacy of its negation: 'The theatrical practice of cruelty, in its action and structure, inhabits or rather produces a nontheological space.' (Derrida 1967, 296). The affirmation can only only open a space defined negatively as not-theological rather than affirmatively expressing its own necessity. Derrida is unobtrusively remobilising the complicity strategy, making Artaud's affirmation hostage first to the negation of God and then to the representative logos of metaphysics and the western stage.

Derrida consolidates his position by aligning the theological stage with representative logos: 'The stage is theological for as long as it is dominated by speech, by a will to speech, by the layout of a primary logos which does not belong to the theatrical site and governs it from a distance. The stage is theological for as long as its structure, following the entirety of tradition, comports the following elements: an author-creator who, absent and from afar, is armed with a text and keeps watch over, assembles, regulates the time or the meaning of representation, letting this latter represent him as concerns what is called the content of his thoughts, his intention, his ideas.' (Derrida 1967, 296) The new logos of mis en scène has implications for the pairing of representation and presence: 'The stage will no longer operate as the repetition of a present, will no longer represent a present that would exist elsewhere and prior to it, a present whose plentitude would be older than it, absent from it, and rightfully capable of doing without it: the being present to itself of the absolute Logos, the living present of God.' (Derrida 1967, 299) Derrida seems to 
grant the purity of Artaud's affirmation by describing the theatre of cruelty as 'a space produced from within itself and no longer organised from the vantage of an other absent site, an illocality, an alibi or invisible utopia.' (Derrida 1967, 300) Yet while freeing the stage from the divine logos, Derrida leaves it bound to the ruins of the old stage that it must continue to inhabit or haunt.

By approaching the theatre of cruelty via the logos and remaining silent about chaos, Derrida surgically removes from Artaud's thought the cardinal, energetic idea of chaos, the affirmative power that opens new spaces without implicating them in negation. In 'Mis en scène and Metaphysics' chaos takes the place of the One in energising the procession of the other ideas. By restricting Artaud's perverted Platonism to the ideas of the logos and being, Derrida deprives it of the energy necessary to sustain its affirmation and forces it to fall back on the energy released by negation. By maintaining the unobtrusive sovereignty of the One, Derrida's reading of Artaud keeps it within the law of representation, even when it most violently seems to step out of it. The anarchic energy of chaos that drives affirmation without reference to law or transgression - one that Derrida clearly understands as Artaud's objective for the theatre of cruelty - is literally disempowered by the suppression of the idea of chaos. The implications of this suppression reverberate throughout the essay, in the fear of the 'anarchy' of improvisation or the irony concerning the 'happenings' (a movement in American art that stands in direct lineage to the reading and translation of Artaud in Black Mountain College during the early 1950s). Thus the gestures of the second part of the essay that distance Artaud from representation and repetition are literally gestures, for a reading that excludes the cardinal idea of chaos disempowers Artaud and lends a histrionic air to his signals from the pyre.

The end of Derrida's essay is nevertheless drawn back to the idea of chaos so carefully evaded throughout. It cites and interprets Artaud's 'organised anarchy' out of which theatre is born as an impossible attempt to achieve a 'theatre without representation'. Yet the chaos Artaud saw in 'organised anarchy' is again interpreted as a suicidal energy that includes death as one of its possibilities: 'The energy of Western theatre thus lets itself be encompassed within its own possibility, which is not accidental and serves as a constitutive centre and structuring locus for the entire history of the West.' (314) The corollaries of this confinement to possibility or what Artaud called the reign of 'simplicity and order' include the penetration of presence by representation, of affirmation by repetition and the act of erasure 'that confirms the transgressed law' (Derrida 1967, 314-15) Anarchy is called to its organisational limit, and theatre to the 'space of tragedy,' yet there 
is also an energy working at this limit between possibility and impossibility which points to the working and underworking of chaos.

The word with which Derrida is forced to conclude his essay is 'fatal,' a term he has prepared carefully in distancing of himself from Artaud. Derrida's fatality undoes all Artaud's intentions, it is 'the fatal limit of cruelty which begins with its own representation' (Derrida 1967, 316) a 'circular limit' or 'cruelty as the unity of necessity and chance' (Derrida 1967, 316) or 'the cruel powers of death and play which permit presence to be born to itself, and pleasurably to consume itself through the representation in which it eludes itself in its deferral' (Derrida 1967, 316). And if not dialectical, this movement is nevertheless chiasmic - it is the tragic, the closure of representation 'not as the representation of fate, but as the fate of representation'(Derridea 1967, 316). Derrida leaves us with the task of thinking this fatal chiasmus: 'And it is to think why it is fatal that, in its closure, representation continues.'(Derrida 1967, 316). But to end thus, with fatality, is to repeat the gesture of containing Artaud's chaotic Platonism that is constitutive of this essay. For in his perverted neoplatonic hierarchy presented in 'The Mis-en-scene and Metaphysics' Artaud places the idea of fatality in a pivotal place between the ideas of becoming (perverted 'being') and chaos (the perverted 'One').

In his reading of 'Lot and his Daughters' Artaud locates fatality in what The Theatre and its Double will call 'organised anarchy'. Strictly Platonic, the idea of fatality is participated through 'the solemn way in which all forms are organised or disorganised beneath it' some 'bending between an irresistible wind of panic' others 'motionless and almost ironic' (Artaud 1976, 230). Fatality is the idea of possibility and impossibility identified by Derrida as 'tragic' or the closure of representation prior to the world governed by the idea of becoming. But while Derrida ends here, for Artaud fatality is a mid-point in his chaotic hierarchy. Fatality participates chaos and is cited by Artaud alongside the ideas of the 'miraculous,' and 'equilibrium'. And just as negative theology departed from the premise of the impossibility of henology, all logical discourses of 'the One' so too Artaud's idea of Chaos cannot be expressed by the logos, the 'impotences' and 'uselessness' of speech shown in 'this supremely physical and anarchic painting' (Artaud, 230). Derrida, that is to say, tarries in the dialectical oppositions of the realm of the idea of fatality, confining Artaud there without acknowledging the full force of his chaotic metaphysics nor the insane majesty of his perverted Platonism. 


\section{Drawing, or the Scene of the Word}

Artaud's almost programmatic statement that the mis-en-scene of a chaotic metaphysics can discerned better in painting than in speech corresponds to a shift from theatre towards drawing and painting. But his practice is firmly situated with respect to the idea of chaos. Derrida too must move his front and forsake Artaud's theatre for his drawings and painting. The task of neutralising Artaud's chaotic mis-en-scene is engaged at the very outset of his 1986 'Forcener le subjectile' published alongside Paula Thévenin's essay 'La recherche d'un monde perdu' in Artaud Dessins et portraits. The first sentence announces a return to the problem of the mis-en-scene, but rephrasing it in terms of force and the subjectile: 'I would call this a scene, the scene of the subjectile, if there was not already a force at work there to spirit away what always sets up the scene: the visibility, the element of representation, the presence of a subject, even an object.' (Derrida 1986, 55). Orienting Artaud's mis-en-scene according the scene of the subjectile and the light-fingered force that already thieves or 'spirits away' (subtiliser) what sets the scene, Derrida not only returns us to the thieving souffleur but once again diverts our attention away from the chaotic Platonism that energised Artaud's mis-en-scene of metaphysics. Derrida foregrounds the subjectile, opening an extended reflection on what is neither subject not object, but rather the throw, or the 'force before form'. Yet viewed against the backdrop of Artaud's procession of ideas, this throw is but the vehicle of participation - methexis - 'The subjectile: itself between two places. It has two situations for itself. As the support of a representation, it's the subject which has become a gisant, spread out, stretched out, inert, neutral...It is then treated otherwise: as that which participates in the forceful throwing or casting, but also, and for just that, as what has to be traversed, pierced, penetrated in order to have done with the screen, that is, the inert support of representation' (Derrida 1986, 63).

Derrida situates Artaud's pictograms according to the 'rhythmical projection and the inscription of a projectile' (Derrida 1986, 65) thus holding them within the sphere of participation - radicalizing methexis by making it an ungovernable throw rather than a transparent medium. Artaud is conceded his step beyond the Latinity against which he raged and the moribund 'clear ideas' expressed in the Western theatre and its metaphysical analogues that he despised, but only as a force for destabilisation. Derrida's pictograms and their subjectiles 'destabilise the proposition, that is to say a certain historical relation between the subject, the object and the subjectile.'(Derrida 1986, 66) Unfortunately such destabilisation of methexis, such burning of holes in participation, fails to immunise against disturbance at more fundamental levels. For Artaud's perverse Platonism locates 
disturbance not only in participation but more disturbingly at the level of the cardinal ideas replacing the One with Chaos and letting the substitution wreak its due consequences on any attempt to participate either it or the procession of ideas whose course it perverted. Derrida, however, restricts disturbance to the realm of participation, opening himself to the suspicion that he has left intact the eidetic structure that Artaud deranged. The corollary of this restriction is that despite appearances, 'Artaud' has a rational kernel, an intact structure disrupted only in its expression. The pictogram is held within the limits of participation (understood since Descartes in terms of 'representation'): 'Pictogram will designate from now on this destabilisation become work' (Derrida 1986, 66) That is to say, Artaud's ambition completely to derange not only the communication but the essential structure of the ideas is restrained within the limits of a permitted destabilising of the participation of an intact or immunised structure. In Artaud's terms, Derrida has mistaken him for Lewis Carroll.

After preparing this defence in 'Forcener le Subjectile', Derrida is forced finally to confront the 'exemplary' 1931 lecture 'La Mise en scène et la métaphysique' in order to quiet the memories of Artaud's chaotic Platonism. His reading scrupulously avoids Artaud's perversion of the procession of ideas, tirelessly translating this derangement into a disturbance of participation. He begins by citing a passage from Artaud's essay that occurs after the introduction of the perverse ideas, a citation that he truncates and severs from its place within a parenthesis. In the essay Artaud has arrived at the point of reflecting on the methexis appropriate to his perverted, chaotic Platonism. It will no longer have to do with the logos or with language but 'consists of everything that occupies the stage, everything that can be manifested and expressed physically on a stage and that addresses itself first to the senses instead of addressing itself to the mind, like the language of speech.' (Artaud 1976, 231) He follows this with a parenthesis in which he admits that 'I am quite aware...' conceding that in some circumstances words have their place in this physical manifestation. Derrida however suppresses the context, erases the parenthesis and deletes the formula Artaud uses when rebutting obvious and perverse misunderstandings of what he is saying 'Je sais bien..." By editing Artaud in this way, Derrida transforms his rebuttal into a statement of principle, linking his comments on intonation with the problematic of language as subjectile. Yet he deletes - for obvious reasons - the later part of the parenthesis where Artaud dismisses precisely this view of language as a 'subordinate aspect of language for the playwright' with the formula 'So I shall not consider it' (Artaud 1976, 232). The discussion that for Artaud barely merited a parenthesis returns in 'Forcener le subjectile' as the point of departure for Derrida's reading, one perversely legitimated by 
citing Gide (!) and converting Artaud's mis-en-scene governed by the idea of chaos into the 'drama of the subjectile'. His subsequent citations from the essay - described as 'exemplary' with respect to the drama of the subjectile - focus on the Lucas van den Leyden painting, but with no reference to the perversion of Platonism that organises Artaud's reading of it.

In approaching the painting Derrida cites a paragraph where Artaud draws an analogy between watching a firework display and the effects of the sound and lights on perception. He fails to stipulate that this section of the essay moves from methexis as fire towards the ideas of chaos that it participates. Artaud seems to describe the subjectile as 'an element that is still active and mobile in an immobilised form' (Artaud 1976, 229), one that serves 'by its very violence, to counterbalance in the mind the physical solidity and weight of the rest' (Artaud 1976, 229) but as an explicit propadeutic for the contemplation of perverted ideas. For Derrida it serves as a cue to jump to the end of the essay and Artaud's reflections on metaphysics, speech and incantation contrasted with the sensuous mis-en-scene of the oriental theatre that 'has retained intact the secrets of using gestures, intonations and harmony in relation to the senses and on all possible levels.' (Artaud 1976, 239) Artaud's essay ends with this affirmative gesture towards a inflammatory participation of the chaotic ideas through the senses and not the logos. Derrida however chooses to read this affirmation as pure destruction, overlooking that Artaud's last words involve the specific destruction of hindrances to the free exercise of thought. And this is best described in Artaud's earlier description of the Balinese performers as 'these metaphysicians of natural disorder' whose thinking dance is 'a metaphysical struggle, [in which] the rigidity of the body in trance, stiffened by the surge of the cosmic forces invading it, is admirably expressed in this dance, both frenzied and full of rigidity and angles, in which one suddenly senses the beginning of the headlong fall of the mind.' (Artaud 1976, 225) The invasive cosmic forces issue from the idea of chaos, 'like waves of matter breaking one on top of the other, and rushing from all sides of the horizon to enter into an infinitesimal space of trembling, of trance - and to cover over the void with fear.' (Artaud 1976, 224). The participation of chaos, understood as fire and the senses is here mis-en-scene in terms of waves of matter approaching from 'all sides' of a horizon and focusing on a fulcrum of instability unavailable to consciousness and productive of insecurity.

\section{Mômo or Moma}


The dancer in a frenzied trance, possessed by the idea of chaos, dances through the The Theatre and its Double; but their affirmation of chaos at the end of 'Mise en scène and Metaphysics' is misunderstood by Derrida as destructive violence. The frenzied trance of the Balinese dancer anticipated in the lost, celestial poet introduced into the Correspondance avec Jacques Rivière will return as the Mômo in 1947. The word of spirit that in the poem 'Cry' drove creation into reverse and became the governing idea of chaos re-emerges in Artaud the Mômo as 'the anchored spirit/ screwed into me/ by the psycho-lubricious/ thrust, of the sky' (Artaud 1976, 523). Celestially impaled, freed but also bound in a rigid, frenzied trance, the Mômo can move through every temptation, desire but also every inhibition. He has his own language like that of the voice which called earlier to the angels - o dedi/a dada orzoura/o dou zoura/a dada skizi - but while impaled by the 'idea from beyond the earth' he is also beyond the membrane of the celestial vault, beyond but in a sense also between, forming the very membrane itself. Impalement is the perverse methexis or the participation of the deranged ideas, but now, once the Mômo has been un-padlocked and has left the space of the asylum he need not repeat the experiment since he has become literature. But what of the danger of repeating the correspondence with Rivière, of being displayed as the successfully vanquished limit of a negated institution? What of the danger of repeating this enclosure, not as a poet but a visual artist, displayed as the successfully immunised threat to the museum?

What does it mean when, almost fifty years later, Mômo becomes Moma?

Derrida's caution in Artaud le Moma is evident in both the detournement of Artaud's 1947 title Artaud le Mômo and in his Avertissement. Citing Artaud's immunitory gesture against institutional refusal - you have to accept me as the Mômo - Derrida is wary of any complicity with the institutional Artaud-immunity that he had consistently resisted. And so he begins by carefully delimiting the date of the talk - 16 October 1996 - and its occasion, the exhibition of Artaud's drawings and paintings at the New York Museum of Modern Art (MOMA). Signing his text six years later in 2002 , he describes the talk as an 'attempt to approach' that is to say a precautious approach to the one who called himself 'Artaud the Mômo'. But it is a double precaution, against Artaud but also protecting him from the immunising gesture of exhibiting his work in the museum. For identifying Artaud with the museum hosting his exhibition, changing Mômo to Moma, is not just an irresistible pun but an attempt to disable the Mômo's defences against institutional exclusion or appropriation by identifying him with an institution. But the title was equally a test of the 
museum's defences which was indeed 'not judged presentable or decent by the Moma, quite properly' (Derrida 2002, 11). Resisting identification with Artaud, the museum admitted Derrida's talk but without a title - Jacques Derrida...will present a lecture about Artaud's drawings' ( Derrida 2002, 11-12) - unwittingly repeating the gesture of Artaud's 'Cry'.

Once inside Moma, Derrida voices the Mômo by opening and closing his talk with the 'voice of Artaud' - samples from the recording of Artaud's broadcast Pour en finir avec le jugement de dieu. Derrida thus wraps his voice in the voice of Artaud playing the Mômo, giving him the first and last word. But is he really giving the Mômo the honour of the alpha and omega, is he really risking contagion by such proximity? His sampling from a broadcast that was never broadcast may seem a homage, granting Artaud in New York the voice denied him in France - but only partially and on terms governed by the shape - the beginning and end - of Derrida's talk. Derrida's talk substitutes itself for the body of Artaud's broadcast, most of which is, once again, silenced. By this framing, Derrida runs little risk of ingestion by the Mômo; indeed the 'homage' of reproducing Artaud innoculates against contagion through the homeopathic citation of a particularly histrionic broadcast in which Artaud voices the Mômo as completely mad. For this was not the 'voice of Artaud,' but of Artaud immunising himself against resistance by speaking in the voice of the Mômo.

The question of whether Artaud became the Moma on its or on the Mômo's terms repeats the encounter with Rivière: does he enter literature on its terms or must these terms change in order to admit him. Derrida approaches this question by means of a diversion, not towards the clinical/ critical distinction mobilised by Rivière but another: 'Our question, one of our questions, thus will be, I repeat: what is a coup?' (Derrida 2002, 18) This question provokes a sequence of subquestions beginning with 'What would this have to do today with a museum, and for example an exhibition in a museum such as the Moma?' (Derrida 2002, 18) Derrida begins to respond to these questions thetically : 'To deliver oneself to the force of this coup it is necessary to expose, I want to say expose cruelly, this exhibition.' (Derrida 2002, 18). This is a crucial and complex moment in the controlled undoing of Artaud-immunity, one in which the exhibition is 'exposed' that is to say, its immune defences dismantled. Derrida explores the options: at first he seems to move in the direction of Rivière's strategy by maintaining that the museum is indeed capable of giving hospitality (on its terms) to a singularity such as Artaud, but quickly moves to disabuse his audience of this fantasy. Feigning gratitude for the reaffirmed and thus betrayed singularity of 'the chance offered by the museum, the chance of a hospitality for which one must give thanks, because a 
museum only shows original works and bans in principle reproduction' (Derrida 2002, 18) Derrida avoids the recourse to Rivière's strategy but with reference to the museum rather than literature. The madman may be admitted to the museum on its terms, but might the Mômo not devour the Moma? And is not the chance in question one that the event of Artaud might strike the museum, disable its defences and turn Moma into Mômo?

Derrida's ambivalence is almost painful at this point, and is expressed in a sequence of Artaudimmune assertions: 'In my case' I 'do not always like or approve the philosophical or political content...' 'I resist in particular everything in this work that...' I passionately admire Artaud while 'I am also tied to a kind of reasoned detestation, a resistant antipathy...' I am in 'a kind of incessant war that, like antipathy itself, makes Artaud a privileged enemy...' (Derrida 2002, 19) It is an antipathy that 'resists but remains an alliance, it commands a vigilance of thought, and I dare to hope that Artaud, the spectre of Artaud, would not have disavowed it.' (Derrida 2002, 20). Aware of the resistance of the MOMA to the Mômo - not even the title of his talk is acceptable - Derrida seeks to protect the Mômo, standing in for the defences against repressive institutions that he thinks Artaud has already disabled in a suicidal autoimmune gesture. Yet he is also aware that to guard Artaud's body against the blows that it invites - to be his immune defence - simplifies and undermines the very defences of Artaud's immunity.

Towards the end of his performance Derrida returns to his vigilant alliance with the spectre of Artaud against the institutions including himself. He asks himself, or rather the spectre asks him, what is he doing in Moma? All his previous visits to the museum seem but preparations for the arrival of Artaud - it had not existed until he came and occupied it. This is not a matter of 'the visitation or visible apparition of Antonin Artaud in a temple of the visual arts, nor the assumption of the revenant Artaud in the sky of the New World or the great sperm bank of painting, not the rapture or abduction of Saint Artaud in this religious site of modern art' (Derrida 2002, 99). None of this, 'but the return of Artaud-Momo' for whose spectre Derrida imagines himself to be the bodyguard or 'garde de corps' but only for 'an instant'. Although he was perilously close to joining Paula Thévenin in her attempt to constitute an immune defence for the legacy of Artaud, he draws or rather is pushed back. And while Derrida can hear Artaud's modulation of coup and corps - and so divine the strategy of Artaud-immunity that identifies the body with the blows it suffers, the right to speak lodged in the court of Jacques Rivière - in the face of this non-suicidal affirmation Derrida as so often before prefers to cite a 'No' before moving to disable Artaud's immunity: 'Poor Artaud. 
What happened to him. Nothing would be spared him, the Mômo. Nothing. Not even the survival of his spectre, not even the most equivocal and cruelly ambiguous, the most vain and anachronistic of revenges' (Derrida 2002, 104). The Mômo is buried alive in the Moma, or rather the spectre of the Mômo is immolated in the museum. Derrida laments and pities his disgrace, but not without a trace of bad conscience.

Yet as so often in Derrida's readings of Artaud, another, affirmative non-suicidal reading is also possible. Nothing was spared Artaud, because Artaud's autoimmunity was sufficiently disabled not just to absorb all the blows in a paroxysm of suffering but to become the blows in all senses of the term. It becomes the Mômo or celestial poet to be open to all blows. In another reading of Artaudimmunity, the blows can be invited for reasons other than the pathos of suicide or self-destruction; the disabling of immune defences on Artaud's part is undertaken from a position of strength and life, not from weakness and death. The blows aimed by the institutions encounter not a suffering body but an ideal chaos which absorbs and returns their energy. In his Artaud wars, Derrida sometimes appreciated this in his mad enemy, but his recognition of the complexity of Artaud-immunity is quickly reduced to replaying a suicidal gesture. Artaud's Nietzschean freedom from the spirit of revenge - the ability to absorb blows without ressentiment, without responding to them on the adversary's terms - is in the end pitied by Derrida as susceptibility to 'the most vain and anachronistic revenges'. Artaud is betrayed and his theatre of cruelty reduced to the terms of bourgeois theatre, of transgression and retribution.

Artaud-immunity is a far more complex and sophisticated manoeuvre than the self-destructive or suicidal disabling of immune defences. Artaud himself was fully aware of this, assuming the role of the Mômo or man without defences not as a subtle form of defence but as the assumption of a position beyond offence and defence. The Mômo was indifferent to suicide, the disabling of his own defences or auto-immunity was to enhance chaotic life and never for death. He was not to be reasoned with nor fought against. Indeed, at the end of Derrida's self-declared thirty years war the Mômo emerges as neither his friend nor his enemy, neither his vanquished nor vanquisher, but simply elsewhere. 
My thanks to the members of the seminar 'Artaud and Philosophy' in the Department of Philosophy, University of Paris VIII for their help with reading 'Cry'.

\section{REFERENCES}

Artaud, Antonin (2004) Oeuvres, ed. Évelyne Grossman, Éditions Gallimard, Paris

(1976) Antonin Artaud: Selected Writings, tr., Helen Weaver, ed., Susan Sontag, University of California Press, Berkeley-Los Angeles

Barber, Stephen (2013) The Anatomy of Cruelty Anton Artaud: Life and Work, Sun Vision Press

Derrida, Jacques (1967) Writing and Difference, tr. Alan Bass, Routledge, London and New York 200

(2002) Artaud le Moma, Éditions Galilée, Paris

(2005) Rogues: Two Essays on Reason, trs., Pascale-Anne Brault and Michael Nass, Stanford University Press, Stanford

Derrida, Jacques and Thévenin, Paule (1986) Antonin Artaud: Dessins et portraits, Gallimard, Paris Esslin, Martin (1976) Antonin Artaud: the Man and his Work, Calder Publications, London

Peeters, Benoît (2013) Derrida: A Biography, tr. Andrew Brown, Polity, Cambridge 